\title{
Efektivitas Guided Note-Taking berbasis Digital terhadap Retensi Pengetahuan dan Writing Self-Efficacy Mahasiswa PGSD pada Pembelajaran Konsep Dasar IPA
}

\author{
Leo Muhammad Taufik ${ }^{\text {a, } 1^{*} \text {, Noor Novianawati }}{ }^{\text {b, } 2}$ \\ a, b Pendidikan IPA, Universitas Muhammadiyah Cirebon, Indonesia \\ ${ }^{1}$ leotaufik.edu@gmail.com* ; ${ }^{2}$ noor.novianawati@umc.ac.id \\ *korespondensi penulis
}

\section{Informasi artikel \\ Received : \\ December26, 2019. \\ Revised : \\ January 12, 2019. \\ Publish : \\ January 31, 2020.}

Kata kunci:

Guided note-taking

Retensi

Writing self

efficacy

Konsep dasar IPA

\section{Keywords:}

Guided note taking

Retention

Writing self

efficacy

Science

\begin{abstract}
ABSTRAK
Penelitian ini bertujuan untuk menguji efektivitas strategi guided note-taking berbasis digital terhadap retensi pengetahuan dan writing self-efficacy mahasiswa PGSD pada pembelajaran Konsep Dasar IPA. Metode quasi experiment dengan pretest-posttestretest design digunakan untuk mencapai tujuan yang telah ditetapkan dalam penelitian ini,. Hasil penelitian ini mengindikasikan bahwa guided note taking berbasis digital mengembangkan retensi pengetahuan sebagian besar siswa pada kategori baik. Strategi guided note taking dapat membantu mahasiswa calon guru SD untuk menyimpan informasi tentang konsep IPA. Pengujian statistik melalui independentsamples t-test menghasilkan Sig (2-tailed) sebesar 0,000 $<0,05$. Nilai signifikansi yang dihasilkan menunjukkan bahwa penerapan guided note taking berbasis digital melalui penggunaan Google Classroom efektif untuk membedakan writing self efficacy kelompok kontrol dengan kelompok eksperimen. Proses review atau meninjau kembali catatan yang telah dibuat merupakan aspek kritis dalam proses penyimpanan informasi dan fitur assignment pada Google Classroom memfasilitasi proses tersebut menjadi lebih mudah. Berdasarkan temuan penelitian ini dapat disimpulkan bahwa strategi GNT yang berupa handout digital berbantuan Google Classroom memberi efek positif pada penampilan akademis siswa.
\end{abstract}

\begin{abstract}
Effectiveness of Digital-based Guided Note-Taking Through Knowledge Retention and Writing Self-Efficacy of Preservice Elementary Teachers in Learning Basic Concepts of Natural Sciences. This study aims to examine the effectiveness of digital-based guided note-taking strategies on the retention of knowledge and writing self-efficacy of preservice teacher in learning the Basic Concepts of Natural Sciences. The quasi experiment method is used to achieve the goals set in this study, with pretest-posttestretest design. The results of this study indicate that digital-based guided note taking develops knowledge retention of most students in both categories. The guided note taking strategies can help preservice teachers' to store information about the concept of basic natural science. Statistical testing through independent samples t-test resulted in Sig (2-tailed) of 0,000 <0,05. The significance value shows that the application of digital-based guided note taking trough the use of Google classroom was effective in distinguished writing self efficacy between the control group and experimental group. The reviewing notes that have been made is a critical aspect in the process of storing information and the assignment feature of Google Classroom's facilitates the process to be easier. Based on this finding, it can be concluded that the GNT strategy in the form of digital handout assisted by Google Classroom has a possitive effect on students' academic performance.
\end{abstract}

Copyright $\mathbb{C} 2020$ (Leo Muhammad Taufik \& Noor Novianawati). All Right Reserved

How to Cite: Taufik, L., \& Novianawati, N. (2020). Efektivitas Guided Note-Taking berbasis Digital terhadap Retensi Pengetahuan dan Writing Self-Efficacy Mahasiswa PGSD pada Pembelajaran Konsep Dasar IPA. Jurnal Inspirasi Pendidikan, 10(1), 63-69.

This work is licensed under a Creative Commons Attribution-ShareAlike 4.0 International License. Allows readers to read, download, copy, distribute, print, search, or link to the full texts of its articles and allow readers to use them for any other lawful purpose. The journal hold the copyright. 


\section{Pendahuluan}

Pemanfaatan perangkat komputasi seluler di dalam kelas membawa tren baru dalam teknik mencatat. Kemudahan, kecepatan dan keterbacaan merupakan tiga atribut positif yang disediakan oleh teknik mencatat secara digital. Kelebihan teknik mencatat secara digital menjadi dasar preferensi siswa untuk lebih memilih catatan digital dibandingkan catatan konvensional atau dengan tulisan tangan (Duhon, 2015). Pada dasarnya terdapat banyak cara untuk mencatat misalnya dalam bentuk textual outline, catatan terbimbing (guided note), peta konsep (concept maps) ataupun web. Bentuk catatan dibuat tergantung pada tujuan atau kepentingan mencatat itu sendiri. Setiap orang memiliki sejumlah kepentingan yang beragam saat mencatat, misalnya untuk belajar, meningkatkan retensi jangka panjang dan untuk kepentingan dokumentasi kegiatan (Friedman, 2017). Dalam rancangan penelitian ini dikembangkan strategi guided note taking (catatan terbimbing). Strategi guided note taking banyak digunakan oleh guru-guru sekolah menengah dalam upaya membimbing siswa khususnya dalam membantu mereka menyiapkan kuis, tes ataupun ujian (Haydon, et al., 2011). Strategi guided note taking merupakan strategi mencatat yang sederhana, guru dapat menyiapkan selebaran berisi peta atau outline (garis besar) materi ajar yang dikosongkan pada beberapa bagiannya. Bagian yang dikosongkan merupakan informasi penting yang dapat berupa fakta-fakta kunci, definisi, konsep penting atau informasi penting lainnya.

Gagasan tentang efikasi diri telah dipelajari secara luas dalam bidang pendidikan, namun Masshady, et al. (2015) menegaskan bahwa implikasi self-efficacy terhadap kemampuan membuat catatan belum pernah diselidiki. Penelitian Masshady, et al., (2015) yang berjudul "Self Efficacy and Prediction of Note-Taking Inclination among Undergraduate Translation Students" memiliki keunggulan dalam kebaruan topik yang diangkat. Self-efficacy merupakan topik yang relatif baru dalam penelitian penerjemahan khususnya yang berfokus pada minat dan pembelajaran. Penelitian tersebut juga fokus menyoroti perbedaan self-efficacy dalam membuat catatan berdasarkan gender. Penelitian tersebut mengindikasikan bahwa efikasi diri siswa dalam menulis merupakan prediktor kinerja siswa dalam menulis catatan yang efektif. Keterbatasan yang terdapat pada penelitian tersebut yaitu ditinjau dari minimnya kemampuan yang dikaji yakni sebatas pada interpretasi saja. Berdasarkan keterbatasan yang ditemukan pada penelitian tersebut maka terdapat peluang untuk mengkaji lebih dalam tentang strategi pencatatan terhadap writing self-efficacy.

Penggunaan fitur "assignment" pada aplikasi Google Classroom memfasilitasi guru untuk meninjau hasil catatan siswa. Fitur "assignment" juga memungkinkan bagi guru untuk memberi umpan balik terhadap kualitas catatan yang siswa buat. Umpan balik yang diberikan oleh guru menjadi bagian yang sangat krusial bagi terbentuknya efikasi diri siswa dalam menulis. Sebagaimana hasil penelitian van Blankenstein (2018) yang menunjukkan bahwa beberapa siswa yang terlibat dalam penelitiannya menyebutkan bahwa aktivitas menulis lebih menyenangkan ketika mereka mengetahui hasilnya.

Hasil Penelitian Oppenheimer dan Mueller (2012) menunjukkan bahwa catatan tradisional (berbasis paper and pencil) memiliki efek yang sama besar dengan catatan berbasis komputer ketika siswa diuji dengan jenis pengetahuan faktual. Hasil penelitian tersebut juga mengungkap bahwa siswa yang mencatat berbasis digital menyandikan lebih banyak konsep dibandingkan dengan siswa yang mencatat secara tradisional. Lebih banyaknya jumlah catatan yang disandikan oleh siswa melalui catatan berbasis digital mengindikasikan bahwa penggunaan catatan digital meningkatkan kuantitas catatan yang disandikan tetapi hal tersebut tidak cukup untuk meningkatkan belajar metakognitif pada tingkat yang lebih tinggi. Kuantitas catatan akan bermanfaat bagi siswa tetapi hal tersebut tidak dapat menjamin kualitas sebuah catatan, oleh karena itu diperlukan pengujian lebih lanjut untuk mengetahui kualitas catatan yang dibuat siswa.

\section{Metode}

Penelitian ini dirancang untuk menguji tingkat efikasi menulis mahasiswa sebelum dan setelah diberikan intervensi berupa penerapan strategi guided note taking. Desain penelitian ini menggunakan dua kelompok subjek yaitu kelompok kontrol dan kelompok eksperimen. Jumlah sampel pada kedua kelompok subjek masing-masing adalah 28 orang mahasiswa program studi pendidikan guru sekolah 
dasar (PGSD) tahun akademik 2019/2020. Penjaringan data penelitian dilakukan sebelum dan setelah diberi perlakuan, sebelum perlakuan dalam bentuk pretest, setelah perlakuan dalm bentuk posttest dan retest. Retest dilakukan setelah selang waktu empat minggu dari pembelajaran. Kedua kelas sampel dibedakan berdasarkan jenis perlakuan yang diberikan, kelas kontrol diberi perlakuan berupa strategi mencatat tradisional (paper based text) sedangkan kelas eksperimen diberi perlakuan yang berupa strategi guided note taking berbasis digital. Selama kegiatan pembelajaran Konsep Dasar IPA, mahasiswa diarahkan untuk membuat catatan saat menyimak penjelasan dosen. Basis digital merupakan aspek pembeda diantara kedua kelompok sampel. Mahasiswa pada kelompok eksperimen diarahkan untuk terkoneksi pada intermet dan mengakses Google Classroom. Melalui fitur 'assignment' yang telah disediakan dosen pada aplikasi Google Classroom, siswa pada kelompok eksperimen membuat catatan sesuai dengan format catatan yang telah disediakan oleh dosen. Format catatan yang disediakan dosen dalam aplikasi Google Classroom berupa paragraf yang dikosongkan dan ditandai dengan titik-titik pada beberapa bagian. Titik-titik yang dikosongkan merupakan konsep atau ide pokok dari konten yang penting untuk dikuasai oleh siswa. Mahasiswa pada kelompok kontrol dibimbing untuk mencatat secara tradisional berbasis paper and pencil pada handout yang telah disediakan. Mahasiswa perlu mengisi bagian-bagian yang dikosongkan tersebut dengan definisi istilah, fakta kunci atau konsep-konsep penting lainnya. Jumlah paragraf yang disediakan oleh dosen disesuaikan dengan konten yang dibahas saat pembelajaran. Setelah selesai pembelajaran, dosen akan memeriksa serta memberi umpan balik terhadap hasil catatan mahasiswa ketika pembelajaran selesai dilakukan. Melalui aplikasi Google Classroom, mahasiswa mencatat informasi-informasi penting yang disampaikan oleh dosen selama pembelajaran berlangsung.

Teknik penjaringan data dilakukan melalui test dan non-test. Test digunakan untuk menjaring data penguasaan konsep dan retensi pengetahuan mahasiswa tentang Konsep Dasar IPA. Teknik nontest digunakan untuk menjarng data writing self-efficacy serta respon mahasiswa terhadap penggunaan strategi guided note taking berbasis digital pada pembelajaran Konsep Dasar IPA. Data penguasaan konsep dan retensi pengetahuan dijaring dengan menggunakan soal yang sama yang dikembangkan dengan mempertimbangkan jenjang kognitifnya. Pengembangan soal mengacu pada jenjang kognitif versi Revisi Taksonomi Bloom, jenjang kognitif yang ditekankan yaitu level $\mathrm{C} 1$ dan $\mathrm{C} 2$ untuk mengukur tingkat retensi. Pengolahan data dilakukan menggunakan bantuan software Microsoft Office Excel 2010 untuk pengujian data secara deskriptif dan program SPSS versi 20 digunakan untuk pengujian hipotesis. Pengujian hipotesis dilakukan dengan menggunakan independent-samples t-test untuk mengetahui perbandingan kondisi sebelum dan setelah diberi perlakuan pada kelompok yang tidak saling berpasangan. Kelompok yang tidak saling berpasangan dalam penelitian ini yaitu kelompok kontrol (berbasis paper and pencil) dan kelompok eksperimen (berbasis digital)

\section{Hasil dan pembahasan}

Penelitian ini dilakukan di program studi pendidikan guru sekolah dasar (PGSD) dan menggunakan mahasiswa PGSD tahun akademik 2018/2019 sebagai subjeknya. Efektivitas strategi guided note taking terhadap penguasaan konsep mahasiswa di kelas kontrol dan eksperimen secara rinci dapat dilihat pada tabel 1.

Tabel 1. Efektivitas Strategi GNT pada kelas Eksperimen dan kelas Kontrol

\begin{tabular}{ccccccc}
\hline \multirow{2}{*}{ Aspek } & \multicolumn{3}{c}{ Kontrol } & \multicolumn{3}{c}{ Eksperimen } \\
\cline { 2 - 7 } & $\begin{array}{c}\text { Pre- } \\
\text { test }\end{array}$ & Post-test & Retest & Pre-test & Post-test & Retest \\
\hline N & 28 & 28 & 28 & 28 & 28 & 28 \\
\hline X & 48,7 & 77,1 & 69 & 48,9 & 77,4 & 70 \\
\hline SD & 10,3 & 9,7 & 9,4 & 10,8 & 10,8 & 9,1 \\
\hline Nilai tertinggi & 68 & 100 & 84 & 72 & 100 & 84 \\
\hline Nilai terendah & 32 & 60 & 48 & 32 & 60 & 44 \\
\hline
\end{tabular}


Berdasarkan Tabel 1 diketahui bahwa terdapat peningkatan perolehan skor pada kedua kelompok subjek. Nilai tertinggi data post-test diantara kedua kelompok tersebut adalah sama yaitu sebesar 100 dan nilai terendah yaitu 60. Setelah selang waktu tiga minggu dari KBM dilakukan penjaringan data retest untuk mengetahui tingkat retensi mahasiswa. Tingkat retensi mahasiswa dikategorisasi menghasilkan kriteria tinggi, sedang dan rendah. Persentase kriteria retensi mahasiswa secara rinci ditunjukkan pada Gambar 1 untuk kelas kontrol dan Gambar 2 untuk kelas eksperimen.

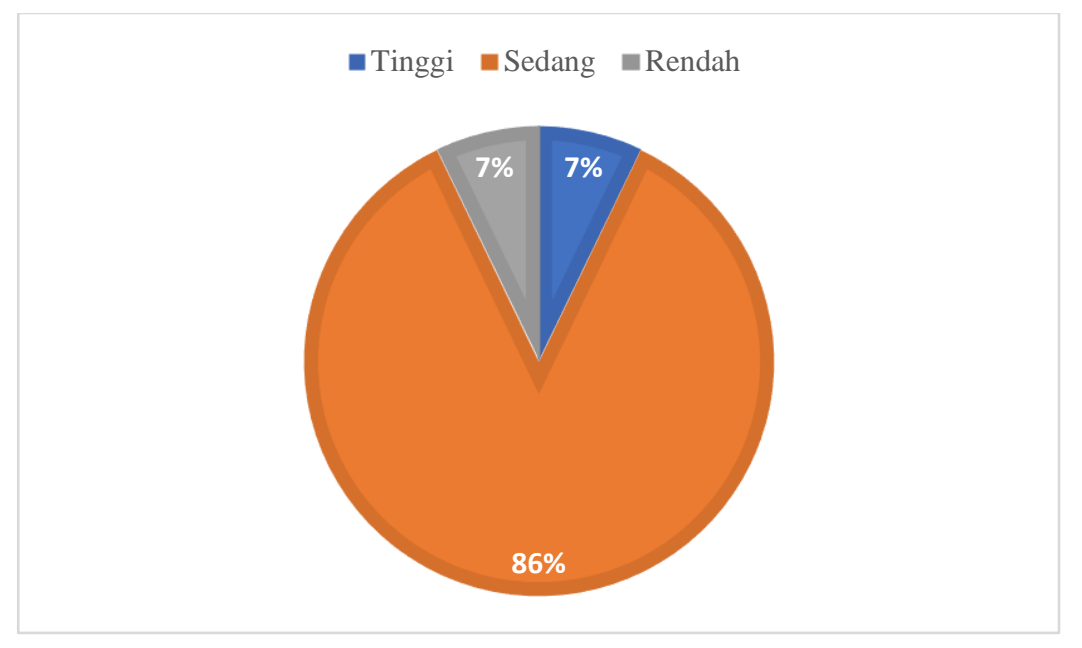

\section{Gambar 1. Kategorisasi Retensi Mahasiswa pada Kelas Kontrol}

Berdasarkan Gambar 1, diketahui bahwa sebagian besar mahasiswa memiliki tingkat retensi pada level sedang dan sebagian kecil lainnya termasuk kategori tinggi dan rendah dengan persentase yang sama besar yaitu 7\%. Level yang berbeda diperoleh dari kelas eksperimen (Gambar 2), yakni sebagian besar mahasiswa (71\%) memiki kemampuan retensi pada tingkat sedang, 29\% lainnya termasuk kriteria tinggi dan tidak ada yang tergolong rendah.

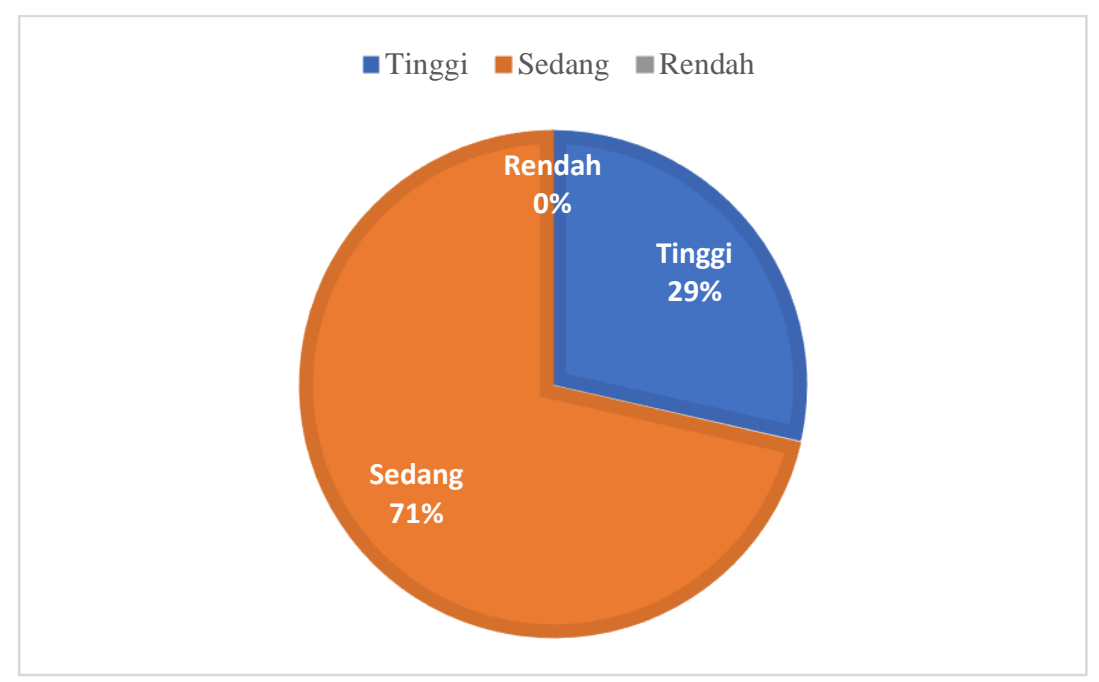

\section{Gambar 2. Kategorisasi Tingkat Retensi Mahasiswa pada Kelas Eksperimen}

Kriteria retensi siswa pada konsep dasar IPA yang dijaring 3 minggu setelah perkuliahan tergolong tinggi. Lebih dari $50 \%$ siswa pada kedua kelompok subjek memperoleh skor retest pada rentang 70-79\% artinya kemampuan siswa mengingat materi konsep dasar ipa berada kategori retensi baik. Pola kategorisasi retensi pada kedua kelompok tersebut berbeda. Predikat retensi pada kelompok kontrol lebih tersebar diantara sangat baik, baik, cukup dan kurang, sebagian besar siswa termasuk pada kategori baik. Predikat retensi siswa pada kelompok eksperimen lebih terpusat pada sangat baik, baik dan cukup. Temuan dari penelitian ini mengindikasikan bahwa strategi guided note taking dapat 
meningkatkan penguasaan konsep serta tingkat retensi mahasiswa. Hasil temuan dari penelitian ini relevan dengan pendapat White (2017) bahwa catatan terbimbing (guided note taking) memandu siswa untuk mengelola konsep-konsep apa yang perlu dipertahankan di luar ingatan mereka. Tingginya tingkat retensi mahasiswa sebagai dampak penerapan guided note taking juga senada dengan hasil penelitian Lawrin \& Lawrin (2013) yang menemukan pengaruh catatan terbimbing dapat meningkatkan keterlibatan dan tingkat akurasi informasi yang dicatat dengan benar sebesar $40 \%$. Mahasiswa yang membuat catatan dengan tingkat akurasi yang tinggi cenderung akan menampilkan hasil tes yang tinggi. Fakta ini menekankan pentingnya keterlibatan siswa dalam merekam informasi secara benar selama perkuliahan berlangsung.

Tingginya tingkat retensi siswa yang diukur setelah 3 minggu dari kegiatan belajar mengajar, secara logis dapat disebabkan karena aktivitas mencatat melibatkan banyak proses mental yang terjadi, seperti memusatkan perhatian pada guru, memahami informasi yang disampaikan, mengidentifikasi konsep-konsep penting yang perlu dituliskan dan mengkoordinasikan sejumlah anggota tubuh untuk mencatat atau menghapus catatan. Sebagaimana pendapat Freidman (2017) yang menyatakan bahwa rangkaian proses mental yang terjadi selama mencatat terjadi secara berkesinambungan dalam waktu bersamaan (Friedman, 2017). Semakin banyak aktivitas mental yang terlibat ketika mencatat, maka akan semakin besar kemungkinan informasi tersebut disimpan dalam memori jangka panjang. Proses review atau meninjau kembali catatan yang telah dibuat merupakan aspek kritis dalam memungkinkan pengalihan informasi dari simpanan memori jangka pendek ke memori jangka panjang. Penyimpanan informasi pada memori jangka panjang berdampak pada kemudahan proses pemanggilan kembali informasi tersebut pada situasi yang berbeda (Hikmawati, 2014). Pendapat senada juga disampaikan oleh Duhon (2015) bahwa aktivitas meninjau kembali catatan yang dibuat oleh pebelajar selama pembelajaran atau ketika dihadapkan pada materi ajar merupakan mekanisme penyimpanan informasi yang memfasilitasi retensi pengetahuan.

Efektivitas GNT terhadap writing self efficacy pada kedua kelompok subjek dapat dibandingkan sebagaimana data yang terdapat pada Tabel 2. Ditinjau dari rata-rata kedua kelompok subjek menunjukkan perbedaan yang tidak terlalu mencolok walaupun kelompok eksperimen lebih tinggi dibanding rata-rata kelompok kontrol. Perbedaan kedua kelompok subjek juga dapat ditinjau dari nilai tertinggi post-test. Senada dengan pendapat tersebut, Duhon (2015) menegaskan dampak positif dari penggunaan strategi GNT terkait dengan fungsi pengkodean (encoding) dan fungsi penyimpanan (storage). Kedua fungsi penerapan strategi mencatat terbimbing (GNT) inilah yang menjadi alasan logis

Fungsi pengkodean melibatkan proses perekaman konten, yang pada penelitian ini proses tersebut diwujudkan dalam bentuk catatan terbimbing. Fungsi penyimpanan dari kegiatan mencatat merupakan proses meninjau catatan sebagai mekanisme untuk memfasilitasi retensi. Proses review atau meninjau kembali catatan yang telah dibuat merupakan aspek kritis untuk memungkinkan pengalihan informasi dari simpanan memori jangka pendek ke memori jangka panjang. Penyimpanan informasi pada memori jangka panjang berdampak pada kemudahan proses pemanggilan kembali (recalling) informasi pada situasi yang berbeda (Hikmawati, 2014).

Tabel 2. Keterampilan Writing Self-Efficacy pada kelas Eksperimen dan kelas Kontrol

\begin{tabular}{ccccc}
\hline \multirow{2}{*}{ Aspek } & \multicolumn{2}{c}{ Kontrol } & \multicolumn{2}{c}{ Eksperimen } \\
\cline { 2 - 5 } & Pre-test & Post-test & Pre-test & Post-test \\
\hline $\mathbf{N}$ & 28 & 28 & 28 & 28 \\
\hline $\mathbf{X}$ & 51,41 & 58,37 & 51,74 & 60,85 \\
\hline SD & 3,86 & 2,35 & 3,47 & 2,55 \\
\hline Nilai tertinggi & 57 & 62 & 57 & 64 \\
\hline Nilai terendah & 41 & 52 & 45 & 55 \\
\hline
\end{tabular}


Informasi yang diperoleh dari hasil rekapitulasi nilai writing self efficacy dapat dimaknai jika dilakukan pengujian secara statistik. Sebagaimana Tabel 3 menunjukkan bahwa nilai signifikansi Levene's Test for Equality of Variances adalah sebesar 0,541>0,05 maka dapat diartikan bahwa varians kedua kelompok kontrol dan eksperimen adalah homogen atau sama. Berdasarkan tabel output, nilai Sig (2-tailed) sebesar $0,000<0,05$, maka sebagaimana dasar pengambilan keputusan dalam uji independent sample t-test disimpulkan bahwa H0 ditolak dan Ha diterima. Dengan demikian dapat disimpulkan bahwa terdapat perbedaan yang nyata antara writing self efficacy kelompok kontrol dan kelompok eksperimen.

Tabel 3. Hasil Uji t-test Writing Self-Efficacy kelas Eksperimen dengan Kelas Kontrol

\begin{tabular}{|c|c|c|c|c|c|c|c|c|c|c|}
\hline & \multicolumn{2}{|c|}{$\begin{array}{l}\text { Levene's Test for Equality of } \\
\text { Variances }\end{array}$} & \multicolumn{7}{|c|}{ t-test for Equality of Means } \\
\hline & & \multirow[b]{2}{*}{$\mathrm{F}$} & \multirow[b]{2}{*}{ Sig. } & \multirow[b]{2}{*}{$\mathrm{t}$} & \multirow[b]{2}{*}{ df } & \multirow{2}{*}{$\begin{array}{l}\text { Sig. (2- } \\
\text { tailed) }\end{array}$} & \multirow{2}{*}{$\begin{array}{c}\text { Mean } \\
\text { Difference }\end{array}$} & \multirow{2}{*}{$\begin{array}{l}\text { Std. Error } \\
\text { Difference }\end{array}$} & \multicolumn{2}{|c|}{$\begin{array}{l}95 \% \text { Confidence Interval of } \\
\text { the Difference }\end{array}$} \\
\hline & & & & & & & & & Lower & Upper \\
\hline Writing & $\begin{array}{l}\text { Equal variances } \\
\text { assumed }\end{array}$ & .378 & .541 & -3.815 & 54 & .000 & -2.50000 & .65537 & -3.81395 & -1.18605 \\
\hline & $\begin{array}{l}\text { Equal variances } \\
\text { not assumed }\end{array}$ & & & -3.815 & 53.629 & .000 & -2.50000 & .65537 & -3.81416 & -1.18584 \\
\hline
\end{tabular}

Perbedaan yang secara statistik signifikan mengindikasikan bahwa penerapan strategi guided note taking berbasis digital efektif mengembangkan writing self efficacy mahasiswa PGSD pada konsep dasar IPA. Mencatat dengan menggunakan teknik fill in the blank yang diterapkan pada penelitian ini terbukti mengurangi ambiguitas konsep karena siswa cukup menentukan informasi kritis yang dibutuhkan untuk mengisi bagian yang dikosongkan pada handout. Bagian yang dikosongkan pada handout yaitu informasi kritis yang berupa fakta kunci, definisi ataupun konsep penting dari materi konsep dasar IPA. Dengan teknik mengisi kekosongan, siswa lebih fokus pada bagian yang dikosongkan sehingga dapat mengefisiensikan waktu mencatat dan memberi kesempatan agar siswa dapat terlibat secara aktif pada proses diskusi di dalam kelas. Hasil penelitian ini mengindikasikan bahwa strategi GNT yang berupa handout digital berbantuan Google Classroom memberi efek positif pada penampilan akademis siswa.

Berbeda halnya dengan strategi mencatat yang dikembangkan pada kelas tradisional, beberapa penelitian telah menguji bahwa strategi mencatat secara tradisional membutuhkan keterlibatan siswa pada dua tugas berbeda yaitu mendengar dan menulis dalam waktu bersamaan. Dua tugas yang dikerjakan dalam waktu bersamaan berpotensi menghasilkan efek negatif pada kinerja siswa. Untuk menjalankan dua tugas berbeda dalam waktu bersamaan bukanlah suatu pekerjaan yang mudah. Haydon (2011) menjelaskan bahwa jika siswa berfokus pada salah satu tugas maka kemungkinan terjadinya ketidakakuratan pada tugas yang lain sangatlah besar. Misalnya ketika siswa berfokus untuk mendengarkan penjelasan dosen selama kuliah berlangsung maka dapat menurunkan akurasi dan kelengkapan informasi yang dia catat. Selain itu dia juga dapat kehilangan kesempatan untuk terlibat secara aktif di dalam kelas.

\section{Simpulan}

Berdasarkan hasil penelitian ini dapat disimpulkan bahwa strategi guided note taking berbasis digital secara efektif meningkakan retensi dan writing self efficacy mahasiswa PGSD pada konsep dasar IPA. Proses review atau meninjau kembali catatan yang telah dibuat merupakan aspek kritis dalam memfasilitasi pengalihan informasi dari simpanan memori jangka pendek ke memori jangka panjang. Penelitian ini memiliki beberapa keterbatasan. Pertama, karena terbatasnya jumlah sampel sehingga sulit untuk membuat generalisasi. Kedua, terbatasnya waktu dan kemampuan peneliti. Berdasarkan hasil temuan penelitian ini, dapat direkomendasikan beberapa poin bagi peneliti lain yang tertarik untuk melakukan penelitian sejenis. Penelitian selanjutnya perlu mengembangkan peran guided note taking yang digunakan untuk membantu siswa dalam menerapkan informasi pada tugas di luar perkuliahan selama periode waktu yang panjang. Peneliti selanjutnya juga dapat menentukan efektivitas GNT yang dikombinasikan dengan beragam strategi pembelajaran. 


\section{Referensi}

Duhon, C.A. (2015). Effect of Traditional versus Electronic Note Taking in High School Biology Classroom. Thesis : Lousiana State University. LSU Digital Commons.

Friedman, M.C. Notes on Note-Taking : Review of Research and Insight for Students and Instructors. Harvard University : Harvard Initiative for Learning and Teaching. [Online]. Tersedia : https://hilt.harvard.edu/files/hilt/files/notetaking_0.pdf (20 Agustus 2018)

Haydon, T., Mancil, R. Kroeger, S.D. \& McLeskey, J. (2011). A Review of The Effectiveness of Guided Notes for Students who Struggle Learning Academic Content. Preventing School Failure, Vol. 55 (4), hlm. 226-231. doi: 10.1080/1045988X.2010.548415

Lawrin, K.H., \& Lawrin, D.A. (2013). The impact of guided notes on post-secondary student achievement : A Meta-Analysis. International Journal of Teaching and Learning in Higher Education, Vol. 25 (1), hlm. 47-58.

Mashhady, H., Fatollahi, M. \& Pourgalavi, M. (2015). Self-Efficacy and Prediction of Note-taking Inclination among Undergraduate Translation Students. Theory and Practice in Language Studies, Vol. 5 (11), hlm. 2366-2372. Doi: http://dx.doi.org/10.17507//tpls.0511.22 (29 Juli 2018)

Oppenheimer, Daniel M., \& Mueller, Pam A. (2012). "The Pen is Mightier than the Keyboard: Longhand and Laptop Note-taking." PsycExtra Dataset.

Van Blankenstein, F.M., Saab, N. Van de Rijst, R.M. et al. (2018). How do Self-Efficacy beliefs for academic writing and collaboration and intrinsic motivation for academic writing and research develop during an-undergraduate research project? Educational Studies. Netherlands : Informa UK Limited. [Online]. Tersedia: https://doi.org/10.1080/03055698.2018.1446326 (29 Juli 2018)

White, Justin. (2017). The Effects of Guided and Tradisional note taking on Student Achievement in an Eight Grade Social Studies Class. [Online]. Tersedia : https://mcstor.library.milligan.edu/bitstream/handle/11558/2490/White_Justin_20170602.pdf ?sequence $=1 \&$ isAllowed $=\mathrm{y}$ 